\title{
International Commercial Arbitration as an Alternative Method to Solve International Commercial Disputes
}

\author{
Msc. Bledar Biti \\ University "Aleksandër Moisiu" Durrës \\ avbiti@hotmail.com \\ Msc. Beslinda Rrugia \\ University "Aleksdandër Moisiu" Durrës \\ rrugiab@gmail.com
}

Doi:10.5901/ajis.2014.v3n3p351

\begin{abstract}
The institute of international commercial arbitration, improving especially in the twentieth century, is considered as an important alternative to resolve disputes. Currently, in international commercial contracts the agreement of which way to choose in order to solve possible disputes, occupies a central role in the contractual provisions as a whole. The rapid development of international trade, the increase of investments in foreign countries that operate each with their own legislations, the need for an agreement to be found as soon as possible and for the process as a whole to respect confidentiality and to apply the rules of procedure in a flexible way represent significant reasons why disputing parties prefer international commercial arbitration to judiciary. The analysis of such advantages as well as of the different types of international commercial arbitration with a special attention to the Albanian law concerning international arbitration will be the focus of our paper.
\end{abstract}

Keywords: International Commercial Arbitration, International commercial disputes, the advantages of arbitration, arbitration agreement, arbitration clause, the principle of confidentiality.

\section{Introduction}

The arbitration ${ }^{1}$ as an institute of law represents a private system for reviewing disputes. Parties who choose to arbitrate their dispute have excluded the resolution in any juridical system. In most instances, the arbitration process means a final and binding decision to be implemented. Decision makers (the arbitrators), usually one or three, as a general principle are chosen by the parties. Parties also are those who decide whether the arbitration process will be administered by an international arbitration institution ${ }^{2}$, or ad hoc arbitration ${ }^{3}$. The rules will apply to the administration of the arbitration process are institutional arbitration rules, or other rules chosen by the parties. Besides the selection of arbitrators and the rules to be based on the entire arbitration process to be followed, the parties may choose the place and the language of arbitration. Such a process, gives to the parties substantial autonomy and control to be exercised for resolving their disputes. This is particularly important at international commercial arbitration as the parties do not want to be subject to the jurisdiction of the other party's court system. The arbitration, offers a more neutral forum, where each party believes that, will have a fair hearing.

Furthermore, another characteristic is the flexibility of the arbitration process which means the opportunity to adapt such a process to the parties needs, and the opportunity to select arbitrators who have knowledge in the subject of dispute arbitration, make the arbitration more attractive as an alternative method to resolve disputes.

\footnotetext{
${ }_{1}^{1}$ Huys and Keutgen, page 21, para.21 "a form of dispute resolution which is based on a private agreement and which leads to a decision having res judicata effect. Such decision is the result of the activity of one or more individuals whose power to determine the dispute derives from the common will of the parties"

${ }^{2}$ A. Redfern and M. Hunter 2004, page 47, "An "Institutional" arbitration is one that is administered by a specialist arbitral institution under its own rules of arbitration"

${ }^{3}$ A. Redfern and M. Hunter 2004, page 47 "Ad hoc arbitration si one which is cunducted pursuant to rules agreed by the parties themselves or laid down by arbitral tribunal.
} 


\section{Party Autonomy in Arbitration Process}

The substantial principle of the parties' autonomy in the arbitration process is defined at all laws and international conventions with a focus on arbitration. This important principle consists in itself the core of arbitration as an alternative method of resolving the disputes. Simultaneously it is connected closely with the freedom of parties to choose the method of resolving disputes arising or to be arised in the future. Even the parties based on such a principle have the freedom to design the whole process as per their will.

The autonomy principle of the parties is described from the authors Redfern and Hunter as in the following:

"Party autonomy is the guiding principle in determining the procedure to be followed in an international commercial arbitration. It is a principle that has been endorsed not only in national laws, but by international arbitral institutions and organisations. The legislative history of the Model Law shows that the principle was adopted without opposition..." 4

Even in the important act in the field of arbitration the UNCITRAL Model Law at its article 19/1 it has provided this principle as citated below:

"Subject to the provisions of this Law, the parties are free to agree on the procedure to be followed by the arbitral tribunal in conducting the proceedings". 5

In the same time even at the Act of Arbitration of the UK of the year 1996 at its section 1(b) defines that the dispositions of the first part are founded on important principles on which it is comprised even the principle of the parties'authonomy, highlighting so the importance of such a principle as follows:

"the parties should be free to agree how their disputes are resolved, subject only to such safeguards as are necessary in the public interest." 6

So, the parties'autonomy at an arbitration process is essential. Its importance is found:

- First, for the fact that there might not be an arbitration process without the consent of the parties, and

- Second, if such consent exists than they may decide the assignment of ad-hoc arbitration or an institutional arbitration, assignement arbitrator(s), the procedure to be followed for resovling the dispute, material law and a serie of important elements related to the arbitration process.

Many agreements between parties today include arbitration clauses with an explicit choice of law, and, in keeping with the principle of party autonomy, the parties' choice of law is "invariably" applied by arbitrators?

While the parties have an agreement for the way of resovilng the disputes, the consensual nature of arbitration demands that the way in which they have chosen to resolve their disputes, be respected in every way possible.

\section{The Effectiveness of the Arbitration Process}

The arbitration as an alternative method of resolving disputes it is considered as effective. Its effectiveness is found as an advantage focusing the analysis at its two main features. They are:

- First, the arbitration as a quick means for resolving the dispute, and

- Second, the opportunity that creates the arbitration to maintain the continuity of relations among parties involved in the dispute.

In the Arbitration Act 1996 (UK) it is defined clearly the objective of arbitration is the resolve of the disputes from an impartial tribunal without unnecessary delay or expense.

"..the object of arbitration is to obtain the fair resolution of disputes by an impartial tribunal without unnecessary delay or expense"8

\footnotetext{
${ }^{4}$ Redfern and Hunter, with Blackaby and Partasides, Law and Practice of International Commercial Arbitration, 4th Edition, p 315;

${ }^{5}$ Article 19(1) of the UNCITRAL Model Law;

${ }^{6}$ Section 1(b) of the Arbitration Act 1996 (UK);

7 W.Michael Reisman Et Al., International Commercial Arbitration: Cases, Materials and Notes on the Resolution of International Business Disputes 712 (1997);

${ }^{8}$ Section 1(a) of the Arbitration Act 1996 (UK).
} 
In this way it is seen that the arbitration process cannot be equalized with the court litigation, because its core (of the arbitration) stays on the soonest resolve and without unnecessary expenses. The parties reach to this point through the opportunity that they have to exercise a larger control to manage the time of procedure, the flexibility of the arbitrators to be adapted to the needs and will of the parties to resolve the dispute as soon as possible.

The international commercial arbitration reaches a sooner resolve, because the procedures are less formal than in a court process. The limited right for the appeal against the arbitration decisions means that the resolving of the dispute will not be dragged on in a long appeal process, and in such a way parties reach sooner at a final decision. The sooner the parties resolve the dispute the quicker they may concentrate on their businesses.

The court litigation of commercial disputes has a trend to impinge the business relations judging the parties as well as due to the nature of process development itself which encourages for "revenge".

Anyhow, there will be always a winner and a looser, and the parties, especially from the world of business, are interested to maintain the relations among them and the the only way which offers such an opportunity is the arbitration.

\section{The Arbitration is Less Costly than Court Litigation}

The cost of the arbitration process referring to its ideal form eventually is another advantage whitch it is characterized. Assuming the time is a cost for the parties, the longer the procedure proceeds the more the process will cost. The "Cost" element should be dealed with in complexity with the developments that the international arbitration institute represents today.

There are cases that the arbitration could lead really on high costs. This means that, if the parties have choosen an institutional arbitration (for instance ICC, LCIA) which from the procedures development point of view, are looking like nowadays, more to court litigations where respectively, the costs are higher. These costs, for the parties, would include, travelling expences, accommodation for the arbitrators, fees for the arbitration sessions, and so on. In several processes, there might be raised the need for expertise of a certain field, which means additional costs for the parties, for example:

Article 37/1 "The costs of the arbitration shall include the fees and expenses of the arbitrators and the ICC administrative expenses fixed by the Court, in accordance with the scale in force at the time of the commencement of the arbitration, as well as the fees and expenses of any experts appointed by the arbitral tribunal and the reasonable legal and other costs incurred by the parties for the arbitration". ${ }^{9}$

Such fees and expences are usually encountered at court litigations, which mean that the arbitration is looking like more to court litigations, making it less efficient costwise. These factors give a deviation to the arbitration from its core.

Nevertheless, we should reflect related to this characteristic of the arbitration, as the costs will depend from the attitude of the parties, their representatives and of the arbitrators. In the same time, if we refer to the real nature of the arbitration, this means a quick process, effective, limited appeal right against final decisions of the arbitration, and at last, an efficient cost for the parties. So, the arbitration in its ideal form should be accepted as it is much cheaper than court litigations.

\section{Privacy and Confidentiality}

One of the quoted priorities of the international commercial arbitration, different from the court litigations, is the private procedure as well as the award of the decisions is normally confirdential, unless the parties have agreed otherwise. Such a characteristic of the arbitration is considered proper especially for disputes where companies from the business world are involved.

Anyhow, in an arbitration international commercial process it is important to understand the difference between the confidentiality and the privacy concepts.

The privacy means the fact that, in the absence of an otherwise agreed procedure, the arbitration process is not disclosed for the public ${ }^{10}$. This means that as a general rule of the arbitration process is private compared to the court litigation where the main rule is to be public. According to such a rule, in arbitration process no one else can participate except the parties involved in the dispute.

This attitude is kept even from the authors Redfern and Hunter whom quote that:

\footnotetext{
9 ICC Rules of Arbitration are used worldwide to resolve business disputes through arbitration. The current Rules are in force as from 1 January 2012. Article 37/1 : Decision as to the Costs of the Arbitration

${ }^{10}$ Gary B. Born, International Commercial Arbitration (2009), 2251;
} 
"International commercial arbitration is not a public proceeding. It is essentially a private process and this is seen as a considerable advantage by those who do not want discussion in open court, with the possibility of further publication elsewhere, of the kind of allegations which can and do arise in commercial disputes - allegations of bad faith, of misrepresentation, of technical or managerial incompetence, of lack of adequate financial resources, or whatever the case may be"11

The privacy in such a process compounds a principle and it is important to highlight that is meets completely with the nature and the kind of disputes (international commercial ones). Even ICC Rules of Arbitration which are used worldwide to resolve commercial disputes through arbitration provide similar situation related to the privacy that, without the approval of the court of arbitration and of the parties involved in the dispute, no one else can participate in the process:

"Article 26/3 Hearings

"...The Arbitral Tribunal shall be in full charge of the hearings, at which all the parties shall be entitled to be present. Save with the approval of the Arbitral Tribunal and the parties, persons not involved in the proceedings shall not be admitted."12

Similar attitude is stated even at the most important international act, Uncitral Rules of Arbitration next to the Uncitral Law of Arbitration, sanctioning the privacy as an essential principle in its 28 Article where:

Article 28 Hearings

\title{
...."Hearings shall be held in camera unless the parties agree otherwise... "13
}

While the concept of confidentiality is represented different from the concept of privacy where, first in contents and as second in the way of sanctioning it in the international acts or national law with focus the arbitration. We explain herewith below in more details both facts:

First: The obligation of confidentiality requires the parties not to disclose information about, or information obtained within the arbitral process to third parties ${ }^{14}$. In this way confidentiality in arbitration process is represented as an obligation that the parties should comply with. Such an obligation should be regulated from the parties themselves. They should keep the confidentiality related to a certain information where included, but not limited to: the arbitration process between parties, documents, materials or informations prepared for such a process, facts stated or written, the content of the final decision, and so on.

Second: from the point of view of the sanctioning of such a principle at international or national acts with focus the arbitration, the situation is not harmonized as applied at the privacy principle. Eventually, the national laws have different approaches, even the Model Law UNCITRAL related to the confidentiality of the arbitration decisions forwards to the parties to be regulated or to the arbitration rules preselected from the parties.

Such a situation is quoted even from the United Nations Commission on International Trade Law [UNCITRAL], at Notes on Organizing Arbitral Proceedings according to which:

\begin{abstract}
"There is no uniform answer in national laws as to the extent to which the participants in an arbitration are under the duty to observe confidentiality of information relating to the case. Moreover, parties that have agreed on arbitration rules or other provisions that do not expressly address the issue of confidentiality cannot assume that all jurisdictions would recognize an implied commitment to confidentiality. 15
\end{abstract}

To this purpose, in such a situation, the parties are those who have to provide dispositions in clauses or agreements of arbitration related to the confidentiality and its extent. In all these cases where the parties are not completely clear on the extent of the confidentiality, it is the the arbitration court to advise discussions with the parties

\footnotetext{
${ }^{11}$ Redfern and Hunter, with Blackaby and Partasides, Law and Practice of International Commercial Arbitration, 4th Edition, 2004;

12 ICC Rules of Arbitration are used worldwide to resolve business disputes through arbitration. The current Rules are in force as from 1 January 2012, Article 26/3;

${ }_{13}$ http://www.uncitral.org/uncitral/en/uncitral_texts/arbitration/2010Arbitration_rules.html, UNCITRAL Arbitration Rules (as revised in 2010) , Article 28/2;

${ }^{14}$ Gary B. Born, International Commercial Arbitration (2009), 2251;

15 United Nations Commission on International Trade Law [UNCITRAL], UNCITRAL Notes on Organizing Arbitral Proceedings, 31, U.N. Doc. NCN.9/423 (Oct. 4,1996).
} 
and, as far as is possible to make evident all the principles of non-disclosures for which parties have agreed ${ }^{16}$.

To understand the confidentiality principle there are of interest even the court decisions which are stated in relation with this subject, where one of them it is the decision awarded from English Appeal Cort for the case Hassneh Insurance Co. of Israel v Mew ${ }^{17}$. In the follow there is an abstract from such a case:

\subsection{Background}

The plaintiffs, Hassneh Insurance, reinsured the defendant, Stuart Mew, under various insurance contracts placed by Heath. Arbitration took place, and the defendant was unsuccessful. He therefore wished to proceed against his placing broker, Heath, on the basis of negligence and breach. That action was not the subject of an arbitration agreement, and to prosecute his claim in the courts successfully the defendant sought to utilise the series of documents that had come into his possession during the previous arbitration. The documents included both documents that had specially been brought into existence for the purpose of the arbitration, such as the pleadings, witness statements and transcripts, as well as other documents that the plaintiffs discovered in the arbitration. ${ }^{18}$

The plaintiff, Hassneh Insurance Co., claimed an injunction to restrain disclosures by the defendant of the requested documents. They claimed that it would be a breach of confidentiality. ${ }^{19}$

\subsection{The Court Decision}

Mr Justice Coleman ruled in favour of the plaintiff, and issued an injunction to prevent disclosure of the material. The Judge based his decision on an assertion that the release of the subject documents would amount to a breach of confidence. ${ }^{20}$

It is of interest to highlight that the principle of confidentiality is an important advantageous feature in the arbitration process, notably for the companies of business world, and especially while they have to deal with commercial disputes at which are included intellectual property secrets, where there is a concern of disclosure, damage of the reputation or of the position in the market, etc. In this way, the parties should negotiate with each other for establishing dispositions related to the confidentiality in the clauses or agreement of arbitration.

\section{Arbitrator Selection}

At the International Commercial Arbitration, the will of parties involved in the process is determinant. It is extended at the right to appoint the arbitrator(s) (as person(s)) and the compound of panel even as for its number. Such a right should be considered as an advantage referred to the court litigation. The parties have the right to choose the arbitrators evaluating their qualifications related to the characteristics of the arbitration in subject. Those qualifications may refer to the following elements: subject expertise, reputation of competence related to the dispute in subject, experience, availability, commitment and capability to manage an effective and efficient arbitration process.

The right of the parties to choose arbitrators with particular expertise and competence is of a paramount importance, referred to the court litigation of commercial disputes whre the judge are appointed in random without taking into account whether they are qualified properly for the disputes in subject. Another important advantage is the right to determine the number of arbitrators forming part of the arbitration panel. At UNCITRAL Model Law on International Commercial Arbitration (1985), with amendments as adopted in 2006 it is sanctioned the right of parties to determine the number of arbitrators as quoted below:

Article 10/1. Number of arbitrators

"The parties are free to determine the number of arbitrators...." 21

\footnotetext{
${ }^{16}$ E drejta e Arbitrazhi dhe e Ndermjetesimit Nderkombetar Tregtar, Suela Mëneri, fq. 254

17 Hassneh Insurance Co and others v. Steuart Mew, (1993) 2 Lloyd's Rep. 243 (Q.B (Com Ct.).

${ }_{18} \mathrm{lbid}$.

19 lbid. at 243

20 lbid. at 243-244

21 http://www.uncitral.org/uncitral/en/uncitral_texts/arbitration/2010Arbitration_rules.html, UNCITRAL Model Law on International Commercial Arbitration1985 With amendments as adopted in 2006, Article 10/1
} 
In this law, it is sanctioned even the general rule for the number of arbitrators forming part of the arbitration panel, whether the parties have not provided prior related to the subject:

Article 10/2. Number of arbitrators

"... Failing such determination, the number of arbitrators shall be three..."22

Finally, the international commercial arbitration gives the opportunity to choose the arbitrator or arbitrators with the proper professional knowledge which is only one factor to be considered but not of minor importance related to the reliability and costs of process. Other abilities to be taken into account from parties for the abilities of arbitrators might be; availability, ethics, managerial capacities, experience for careful examination of previous disputes similar to the subject. If the arbitrator or arbitrators hold these features than the arbitration process is much more hopeful.

\section{Albanian Legislation in the Field of Arbitration}

The Arbitration Institute is regulated through a special chapter of the Civil Procedures Code (below referred as C.P.C.) of the Republic of Albania, articles 400 - 439. Examining these articles, it can be seen, a division in two parts consisting on national arbitration and the international one. In this chapter of C.P.C. there are provided the general arbitration rules. Referring to the C.P.C., any propert claim or request deriving from a property relation, might be subject of a judgement of arbitration $^{23}$. The parties are free to choose the method of conflict resolution guaranteeing the principle of parties' autonomy. They have the right to determine only the procedurial rules of arbitration ${ }^{24}$, and the arbitration place ${ }^{25}$. The parties have the right to choose through the arbitration not only eventual conflicts but even those that might arise in the future. Even in case of conflict due to which parties are addressed for judgement in the tribunal jurisdiction, they may reach to an agreement during judgement and may transfer it for resolution at the arbitration. At the C.P.C. it is stated that the arbitration agreement is invalid if it is not determined the way of appointment of the arbitrator(s) and of the dispute subject, if the latter has occurred ${ }^{26}$. For the determination of the rules of procedure the parties have full freedom provided that to respect the principles, guarantees for a due process. The arbitration decisions are of the enforcement form to be applied. The appeal for arbitration decision is limited to precedurial reasons and the competent authority for the examination of appeal is the Appeal Court which may repeal or change the arbitration decision and may decide for the basis of the dispute, but not going beyond the mission of arbitration determined by the parties ${ }^{27}$. There is no appeal form allowed for the decision of the Appeal Court. ${ }^{28}$ The execution of the arbitration decisions is performed in the same way as in the cases of decisions from formal courts.

Despite the provisions in this law for the arbitration it is noticed the need for intervene in structure and its contents. In our legislation, can be noticed the lack of important elements of arbitration such as cases of effects of neglect, the case of the freedom of form at the final stage of the arbitration agreement, etc.

While, as for the dispositions regulating the international arbitration they are rescinded. Referring to the globalization where our society is involved, it is an important and immediate duty to compile new dispositions in full accordance with international acts in the field of arbitration.

\section{Conclusions}

It can be noticed nowadays that the arbitration is playing highly every day an important role in the resolution of international commercial disputes. The Institute of Arbitration provides the opportunity to resolve the international commercial disputes from a neutral desicionmaker and reliable entity. The guarantee for the execution of the final decisions assured this from the international acts (The New York Convention 1958), the parties' autonomy as for procedurial regulations, effectiveness, application of the privacy and confidentiality principles as well as arbitrator selection make this process much more attractive that the court litigations. In conclusion, as the most suitable way to

22 http://www.uncitral.org/uncitral/en/uncitral_texts/arbitration/2010Arbitration_rules.html, UNCITRAL Model Law on International Commercial Arbitration1985 With amendments as adopted in 2006, Article 10/2

${ }^{23}$ Civil Procedure Code of the Republic of Albania, Article 402;

$24 \mathrm{Ibid}$, Article 416;

${ }^{25} \mathrm{Ibid}$, Article 419;

${ }^{26} \mathrm{lbid}$, Article 404;

$27 \mathrm{lbid}$, Article 436;

${ }^{28} \mathrm{Ibid}$, Article 437; 
resolve international commercial disputes, the international commercial arbitration is becoming every day more a massive culture for resolving international commercial disputes.

\section{References}

Civil Procedure Code of the Republic of Albania;

Marcel Huys and Guy Keutgen, "Larbitrage en Droit Blege et International" 1981;

A. Redfern and M. Hunter 2004, with Blackaby and Partasides, Law and Practice of International Commercial Arbitration, 4th Edition, 2004;

Redfern and Hunter on International Arbitration, Redfern, Hunter, et al. (2009);

Gary B.Born, International Commercial Arbitration (2009);

W. Michael Reisman et al., International Commercial Arbitration: Cases, Materials and Notes on the Resolution of International Business Disputes 712 (1997).

Arbitration Act 1996 (UK);

The International Commercial right of Arbitration and Mediation, Suela Mëneri, 2012;

ICC Rules of Arbitration are used worldwide to resolve business disputes through arbitration. The current Rules are in force as from 1 January 2012;

http://www.uncitral.org/uncitral/en/uncitral_texts/arbitration/2010Arbitration_rules.html, UNCITRAL Model Law on International Commercial Arbitration1985 With amendments as adopted in 2006;

http://wwww.uncitral.org/uncitral/en/uncitral_texts/arbitration/2010Arbitration_rules.html, UNCITRAL Arbitration Rules (as revised in 2010); http://www.lcia.org/Dispute_Resolution_Services/LCIA_Arbitration_Rules.aspx\#article29 LCIA Arbitration Rules;

http://www.uncitral.org/uncitral/en/uncitral_texts/arbitration/NYConvention.html Convention on the Recognition and Enforcement of Foreign Arbitral Awards (New York, 1958) (the "New York Convention"); 